\title{
Erratum to: A New Approach for Modeling Sediment-Discharge Relationship: Local Weighted Linear Regression
}

\author{
Ozgur Kisi $^{1} \cdot$ Coskun Ozkan ${ }^{2}$
}

Published online: 14 January 2017

(C) Springer Science+Business Media Dordrecht 2017

\section{Erratum to: Water Resour Manage}

DOI 10.1007/s11269-016-1481-9

After publication of this article we received a request from Dr. Coskun Ozkan to have his name removed from the author list. Due to unforeseen circumstances Dr. Coskun Ozkan did not have the opportunity to participate in the final approval of the manuscript and missed the opportunity to declare that he withdrew from this paper. Dr. Ozgur Kisi agrees with this change. The correct author list is as shown below.

The online version of the original article can be found under doi:10.1007/s11269-016-1481-9

Ozgur Kisi

okisi@ibsu.edu.ge

1 Center for Interdisciplinary Research, International Black Sea University, Tbilisi, Georgia

2 Geomatics Engineering Department, Erciyes University, Kayseri, Turkey 